\title{
Tułacze i nomadzi. O twórczości Sigbjørna Skådena
}

\author{
Vagrants and nomads. About the works of Sigbjørn Skåden
}

This article focuses on nomadic aspect of the Saami writer Sigbjørn Skåden's works. The nomadic nature of his literary projects is seen from the perspective of modernity rather than as a manifestation of ethnicity. The author of the article points out certain nomadic features of Skåden's writings, such as the shifting perspectives on the subject and the world, the polyglot character of the world created, the transgression of boundaries (including the boundaries of literary fiction), and the adoption of different cultural realities. Also present in his works are elements of aggression, provocation and ethical ambiguity.

Key words: Scandinavia's indigenous people, modern Saami literature, nomadic subject, the Wandering Jew-myth, Sigbjørn Skåden

Słowa klucze: ludy rdzenne Skandynawii, współczesna literatura saamska, podmiot nomadyczny, mit Żyda Wiecznego Tułacza, Sigbjørn Skåden

\section{Wprowadzenie}

Czas jest statkiem, który nie rzuca kotwicy, mówi jedno z saamskich przysłów (Gaski 2004), co ilustruje postawę typową dla kultury nomadycznej, postrzegającej wędrówkę nie tylko jako sposób, ale również jako cel życia. W Podmiotach nomadycznych, wpisujących się w tradycje postmodernistyczne Gilles’a Deleuze’a i Jacques’a Derridy, włoska badaczka Rosi Braidotti przywołuje pojęcie podmiotu nomadycznego jako swoistej teoretycznej figuracji, odnoszącej się do współczesnej podmiotowości. Podkreśla tym samym heterogeniczność sposobów namysłu nad podmiotem, który można określać jako feministyczny, ale również postmodernistyczny, postkolonialny, postindustrialny - w zależności od przyjętej perspektywy. Choć idea podmiotu nomadycznego wynika $\mathrm{z}$ inspirowania się oglądem rzeczywistości rdzennych kultur nomadycznych, między innymi takich jak dawna kultura Saamów, nie chodzi w niej jednak o dosłowne doświadczenie nomadyzmu, zauważa Braidotti. Idea ta zakłada raczej taki rodzaj oglądu rzeczywistości, który 
wyrasta ze sprzeciwu wobec zamknięcia w społecznie zakodowanych sposobach myślenia czy zachowaniach. Nomadyczność w takim ujęciu oznacza eksperymentujące i procesualne podejście do swej podmiotowości, do tego, czym jest „ja” i jakim językiem owo ,ja” można wyrażać (Braidotti 2009: 66). Jednym z wyznaczników nomadycznego oglądu świata i człowieka zdaje się ruch uchwycony w figurze wiecznej wędrówki; ruch sprzyjający zmienności perspektyw, odwoływaniu się do różnych poziomów doświadczenia; ruch skutkujący brakiem stabilnego centrum.

W tym miejscu warto również przywołać myśl krytyka sztuki Nicolasa Bourriauda, który zwraca uwagę na ograniczające implikacje związane z przedrostkiem „post”, sugerującym jego zdaniem uzależnienie od „źródła” i „przeżutych” wątków historycznych. Bardziej bowiem interesująca według niego jest postawa takich artystów, którzy „posługują się własnymi, lokalnymi lub narodowymi kodami (swoją biograficzną specyfiką) jako pewnym surowym materiałem i wiążą go z innymi systemami znaczeń" (Bourriaud 2012: 30). Innymi słowy Bourriaud zauważa krystalizowanie się nowej formacji - „alternowoczesności” lub nowoczesności wędrującej, którą definiuje jako dialog biorący pod uwagę współczesne zjawiska, takie jak: globalizacja, emigracja, płynność tożsamości kulturowej. Jego zdaniem postawa alternowoczesna zakłada przepracowanie przeszłości, jednak bez wikłania się w dualistyczne opozycje między tym, co stare, a tym, co nowe. Bourriaud, próbując zobrazować fenomen alternowoczesności, sięga po figurę korzenia przybyszowego (radicant), wypuszczanego przez roślinę nie z centralnie określonego punktu, ale $\mathrm{z}$ wielu różnych miejsc, i pisze o nowoczesności labiryntowej, nielinearnej, będącej „czasoprzestrzenną tułaczką" (Bourriaud 2012: 31).

Pomimo odmiennych punktów wyjścia trudno nie zauważyć pokrewieństwa między namysłem nad rzeczywistością prezentowanym przez Bourriauda a nomadyczną wizją nowoczesności, wyartykułowaną między innymi przez Braidotti. Jednak te dwie figury myślowe odnoszą się do dwóch odmiennych sposobów wchodzenia w reakcję z rzeczywistością. Korzeń przybyszowy w swej wędrówce przenika, pobiera, przetwarza. $Z$ wędrówką nomady może wiązać się przemoc: jego pojawienie się może przynosić destrukcję, destabilizację, demontaż zastanego.

W niniejszym artykule przyjrzymy się twórczości Sigbjørna Skådena (ur. 1976), urodzonego i mieszkającego w Norwegii pisarza tworzącego głównie po saamsku, tłumacza, literaturoznawcy, absolwenta uczelni norweskiej i angielskiej. Symptomatyczne, że jego napisana na uniwersytecie w Tromsø praca magisterska traktowała o trzech klasykach saamskiej poezji: Pedarze Jalvi, Paulusie Utsi i Nilsie-Aslaku Valkeapää (Bortenfor blånene. Kanonisk utvikling innen samisk lyrikk $i$ det 20. århundre, 2004). Natomiast przedmiotem pracy magisterskiej obronionej 
na uniwersytecie w York była twórczość Dereka Walcotta. Lektura tego niedawno zmarłego karaibskiego pisarza niewątpliwie wyczuliła Skådena na zjawisko interferencyjności w kulturze, a także możliwości twórczego wykorzystania materiału mitycznego (Egeland 2017). Do tej pory spod pióra Skådena wyszły dwie książki poetyckie - Skuovvadeddjiid gonagas (Król szewców, 2004) oraz Prekariáhta lávlla (Pieśń prekariatu, 2009), powieści Láhppon mánáid bestejeaddji (Zbawiciel zagubionych dzieci, 2008) i Våke over dem som sover (Czuwając nad śpiącymi, 2014), a także książka faktograficzna dla dzieci Samer (Saamowie, 2012). Zarówno Skuovvadeddjiid gonagas, jak i Láhppon mánáid bestejeaddji ukazały się w języku norweskim w tłumaczeniu autora. Głos Skådena liczy się nie tylko w kontekście kultury saamskiej. Od 2017 roku Skåden pełni funkcję zastępcy przewodniczącego Norweskiego Związku Pisarzy (Den norske Forfatterforening).

Sytuując Skådena na tle rodzimego pejzażu kulturowego, zwrócimy uwagę na wymiar nomadyczny jego literackich projektów. Ich nomadyczność będziemy postrzegać z perspektywy nowoczesności („alternowoczesności”?), traktując nomadyzm raczej jako metaforę postawy życiowej i artystycznej współczesnego podmiotu niż jako przejaw etnicznego zakorzenienia twórczości Skådena.

\section{Literatura Saamów: między tradycją a współczesnością}

Literatura Saamów wyrasta z tradycji oralnej. Mimo że pisane po saamsku teksty o charakterze religijnym pojawiły się już w XVII wieku' ${ }^{1}$, trudno mówić o rozwoju saamskiego piśmiennictwa przed początkiem XX wieku. Jako datę przełomową wskazać można 1910 rok, w którym ukazała się pierwsza świecka saamska książka - Muitalus sámiid birra (Moja książka o Saamach) autorstwa Johana Turiego². Turi opowiadał w niej o życiu codziennym hodowców reniferów przełomu XIX i XX wieku, wplatając w narrację znane mu z przekazów ustnych dawne legendy, mity i podania. Przy tym w wyraźnie negatywny sposób oceniał kolonizowanie kraju przez przybyszów z południa. Dwa lata później ukazała się pierwsza saamska powieść Bøivve-Alggo (Świt) Andersa Larsena (1870-1849), opowiadająca o procesie norwegizowania Saamów morskich³. Natomiast w 1915 roku Pedar Jalvi

\footnotetext{
${ }^{1}$ Do najwcześniejszych zachowanych zabytków piśmienniczych w języku saamskim należą wydane w Szwecji w 1619 r. En lijten Sångebook, huruledes Messan skal hållas, läsas eller siungas på lappesko (Śpiewniczek pouczający jak mszę należy odprawiać, czytać czy też śpiewać po lapońsku) oraz $A B C$ Book på Lappesko Tungomål (Elementarz w języku lapońskim). Autorem obydwu książek był Nicolaus Andreæ, proboszcz z Piteå (Biblioteksbladet 1922: 11).

2 Muitalus sámiid birra z 1910 r. była książką dwujęzyczną, saamsko-duńską. O jej powstaniu, a także ścieraniu się w niej tradycji oralnej z konwencją przekazu pisemnego zob. Sibińska (2015).

${ }^{3} \mathrm{~W}$ najobszerniejszym $\mathrm{z}$ dostępnych $\mathrm{w}$ języku polskim opracowań na temat saamskiej historii kultury, noszącym tytuł Lapończycy, autorzy Ørnulf V. Vorren i Ernst Manker w kontekście
} 
(1988-1916), zainspirowany dziewiętnastowiecznym fińskim ruchem narodowym, wydał Muohtačalmmit (Płatki śniegu), zbiór prozy poetyckiej i wierszy. Metaforyka utworów Jalviego była zakotwiczona w rodzimym krajobrazie (tytułowe „płatki śniegu” metaforyzują moc i potencjał, które w wizji poety wynikną z saamskiego zjednoczenia), a forma prozy poetyckiej pozwalała się domyśleć wpływów Juhaniego Aho i jego szkiców wydawanych na przełomie XIX i XX wieku, którym ich autor nadał określenie lastuja („wióry”) (Lundmark 2016).

Rozkwit saamskiej literatury przynoszą jednak dopiero lata 70. XX wieku, nacechowane ogólną radykalizacją nastrojów politycznych w społeczeństwach Skandynawii, przejawiającą się między innymi rewitalizacją etniczną Saamów. Nie bez znaczenia dla rozbudzenia saamskich ambicji politycznych i kulturalnych była postać poety, nauczyciela i rękodzielnika Paulusa Utsi (1918-1975). Trzy zbiory jego wierszy: Giela giela (Schwytaj język, 1974) oraz wydane pośmiertnie Giela gielain (Schwytaj język w sidła, 1980) i Don čanat mu alccesat (Podążaj ścieżką, 1992) stały się źródłem inspiracji dla poetów młodszego pokolenia. Istotę jego poezji, łączącej opisy ludzi i krajobrazów Północy z refleksją wokół natury języka, oddaje saamski zwrot oahppat giela, który może znaczyć zarówno „nauczyć się języka”, jak i „sprawdzić, czy coś złapało się w sidła”.

W latach 70. zadebiutował też Nils-Aslak Valkeapää (1944-2001), poeta, muzyk, malarz, grafik, znamienity joiker. Działał aktywnie między innymi przy zakładaniu Saamskiego Związku Pisarzy, Związku Muzyków Saamskich, Związku Twórców Saamskich, a także grupy teatralnej Beaivváš, stanowiącej zalążek dzisiejszego Beaivváš Sámi Našunálateáhter w Kautokeino. W latach 1978-1981 był sekretarzem ds. kultury przy Światowej Radzie Ludów Rdzennych (World Council of Indigenous People). Za poetycko-fotograficzną suitę Beaivi, Áhčážan (Słońce, mój ojciec, 1988) otrzymał w 1991 roku literacką nagrodę Rady Nordyckiej. Po raz pierwszy przyznano wówczas nagrodę twórcy reprezentującemu Sápmi. Punkt wyjścia dla liryki w Beaivi, Áhčážan stanowiły zdjęcia zrobione przez podróżników odwiedzających Sápmi w drugiej połowie XIX wieku, a dopełniały je i kontrapunktowały liryczne komentarze poety. Tematycznie Beaivi, Áhčážan wyrastało z północnych krajobrazów i saamskiej mitologii, ze słońcem jako centrum świata i dawcą życia. Wśród centralnych motywów spotykamy ptaki, wędrujące stada, otwarte przestrzenie dające wędrowcowi poczucie wspólnoty, bezpieczeństwa

historycznym dzielą Saamów na: a) morskich lub nabrzeżnych (osadnictwo wzdłuż wybrzeży okręgów Finnamark, Troms, oraz niewielki odcinek okręgu Nordland), b) górskich (nomadyczni pasterze reniferów), c) leśnych (społeczności, którym podstaw egzystencji dostarczały lasy Północnej Szwecji i Finlandii) oraz d) wschodnich, których tryb życia był zbliżony do Saamów leśnych, ale współkształtowała go prawosławna kultura rosyjska (Vorren i Manker 1980). Nazewnictwo polskie, zaproponowane przez tłumacza monografii Vorrena i Mankera, wynika z norweskich terminów: sjøsamer/kystsamer, fjellsamer, skogssamer, østsamer.

${ }^{4}$ Joik - rodzaj ludowego śpiewu Saamów. 
i przynależności. Natomiast strukturę poetycko-wizualnej opowieści nadawał joik ${ }^{5}$. Kolejne projekty poetyckie Valkeapää szły tropem Beaivi, Áhčážan, poszerzając perspektywę o inne kultury rdzenne, co wyraźne jest w jego ostatniej książce Eanni, eannázan (Ziemia, moja matka, 2001). W latach 90. XX wieku artysta stał się niekwestionowanym symbolem odradzającej się kultury Saamów i przyczynił się do tego, że zaczęto postrzegać Sápmi przez pryzmat jego twórczość. Dla saamskich artystów był mistrzem, od którego uczyli się sztuki szukania cząstki siebie w ojczystym języku, tradycji, wyobrażeniach wypływających z silnych związków człowieka z przyrodą, czyli w tym wszystkim, od czego odcinały ich narzucane procesy asymilacyjne. Jednak wpływ Paulusa Utsi, a zwłaszcza Nilsa-Aslaka Valkeapää na saamską literaturę mógł nieść również negatywne skutki - można było go odbierać jako zachętę do sentymentalnego zapatrzenia się w przeszłość i kreowania mitycznego, stereotypowego wyobrażania nie tylko o saamskiej współczesności, ale również o saamskiej literaturze jako wypowiedzi odindywidualizowanej, podporządkowanej esencjalistycznej, nienegocjowalnej wizji tożsamości kulturowej. Jednocześnie już od końca lat 80 . pojawiły się rysy na romantyzującym obrazie saamskich społeczności jako wspólnot żyjących w harmonii ze sobą i z naturą. Między innymi Rauni Magga Lukkari (ur. 1943) swoją poezją przywoływała nie dla wszystkich wygodny temat patriarchalnej opresyjności i związanej z nią przemocy wobec kobiet. Przełomowy pod tym względem był jej Losses beaivegirji (Mroczny pamiętnik, 1986), będący swoistym lirycznym dialogiem między kobietą potulnie akceptującą sankcjonowaną tradycją przemoc a „piszącym ja”, które czuje się częścią współczesnego świata, pragnie szukać swoich dróg wędrówki przez życie, co może oznaczać bolesne odcięcie od dającej poczucie bezpieczeństwa wspólnoty. Jako saamska kobieta „ja” w Losses beaivegirji czuje się podwójnie marginalizowana - z racji swej etniczności i z racji swej płci.

Mimo prób wchodzenia w dyskurs ze współczesnością, podejmowanych przez niektórych saamskich pisarzy, Nøste Kendzior (1950-2006), norweska krytyczka i tłumaczka, znawczyni kultury fińsko-norwesko-saamsko-rosyjskiego pogranicza, niezwykle surowo oceniła w 2001 roku tworzoną w latach 90. XX wieku saamską literaturę. Jej zdaniem ówcześni pisarze nie wykorzystywali w należyty sposób możliwości, jakie niosła ze sobą swoista strefa tranzytowa (norw. transit-rommet), w której na progu nowego tysiąclecia znalazła się kultura Saamów. Twórcy, twierdziła Kendzior, zasklepiali się w nostalgicznie traktowanej historii i tradycji, z rekwizytami takimi jak białe noce, lavvu, vidda ${ }^{6}$ i wędrujące po niej stada reniferów, zamiast eksplorować nowoczesną codzienność, w tym wielkomiejskie przestrzenie, będące rzeczywistością dla wielu z nich (por. Kendzior 2001).

\footnotetext{
${ }^{5}$ Na temat joiku i jego funkcji we współczesnej sztuce Saamów zob. Sibińska $(2015,2016)$.

${ }^{6}$ Lavvu (saam. tradycyjny namiot pasterski) oraz rozległe, pokryte tundrową roślinnością płaskowyże Finnmarku zwane viddą (norw.) stały się synonimem stereotypowo pojmowanej „saamskości”.
} 
Jakby w odpowiedzi na diagnozę norweskiej krytyczki sytuacja po 2000 roku zaczęła stopniowo ulegać zmianie. Tradycja i historia stanowiły i nadal stanowią bardzo ważny punkt odniesienia dla młodych twórców, a obecność we współczesnej świadomości kulturowej Saamów takich artystów słowa jak Johan Turi, Paulus Utsi i Nils-Aslak Valkeapää, wprowadzających w literacki krwioobieg Skandynawii saamskie wierzenia, obyczaje, specyficzne środki wyrazu (joik), pozostaje niezagrożona. Jednak w Szwecji, Norwegii i Finlandii do głosu zaczęli dochodzić pisarze znacznie bardziej zorientowani na współczesną rzeczywistość, w tym na coraz bardziej problematyczne pojęcie tożsamości, w której etniczność stanowi tylko jeden z aspektów. Są to między innymi Ann-Helén Laestadius (ur. 1971, Kiruna). Rawdna Carita Eira (ur. 1970, Elverum), Simon Issát Marainen (ur. 1980, Nedre Soppero), Hege Siri (ur. 1973, Stavanger) czy też interdyscyplinarny artysta Niillas Holmberg (ur. 1990, Utsjoki), którego poezja świadczy o tym, iż „schizofreniczne doświadczenia społeczne młodych ludzi traktuje poważnie (...), z mądrością i wyczuciem” (Uvaag 2015).

Wśród saamskich pisarzy szukających sposobu „na chwytanie w sidła języka” współczesnych Saamów, języka wynikającego z obecnej kondycji człowieka, jest również Sigbjørn Skåden. Omawiając jego poetycki debiut na łamach platformy Versopolis, podkreślono wielowarstwowość tradycji nomadycznej, w którą wpisuje się saamski autor. Między innymi stwierdzono:

The King of Shoemakers wants to give the nomads a voice. The Nordic Countries, northern Scandinavia in particular, have been populated by Swedes and Norwegians since a thousand years, but the countries have also hosted refugee children from Finland, traveling salesmen from Germany, immigrant Wallonian workers, traveling Roma and rejected Saami forcefully converted to Christianity. They all raise their voices in ascending, violent shifting between beautiful praises and scornful showdowns. When The King of Shoemakers reaches its inevitable crescendo those voices are hard to ignore (Jonsson 2017) ${ }^{7}$.

Innymi słowy nomadyzm Skådena wyrasta z pragnienie spotkania, wymiany, przenikania, przekraczania, przechodzenia dalej. Nie charakteryzuje się brakiem granic, ale - sięgając po sformułowanie autorki Podmiotów nomadycznych - „raczej przenikliwą świadomością ich nietrwałości” (Braidotti 2009: 66).

${ }^{7}$ „Król Szewców pragnie udzielić nomadom głosu. Kraje skandynawskie, w szczególności ich północną część, od tysiąca lat zamieszkują Szwedzi i Norwegowie, ale ziemie te przyjmowały także małych uchodźców z Finlandii, przyjezdnych kupców z Niemiec, walońskich imigrantów poszukujących pracy, wędrujących Romów, Saamów siłą nawróconych na chrześcijaństwo. Wszyscy oni podnoszą głosy, które narastając, oscylują między afirmacją a konfrontacją. W chwili, gdy Król Szewców osiąga nieuniknione crescendo, głosy te są trudne do zignorowania" (tłum. M.S.). Cytat przywołuje wydarzenia z lat 1939-1944. Wówczas wysłano z Finlandii 80 tys. dzieci, ratując je przed skutkami działań wojennych; większość dzieci przyjęła Szwecja, część trafiła do Norwegii. 


\section{Nomadyzm, czyli płynność granic}

Jako miejsce urodzenia Sigbjørna Skådena wskazuje się Tromsø, ale ziemią rodzinną pisarza jest gmina Skånland w południowej części dystryktu Troms. Przekraczanie granic - geograficznych, językowych, mentalnych, etnicznych - było wpisane w proces powstawiania tamtejszych społeczności saamskich. Skåden przynależy bowiem do márkosámit (norw. markasamer), czyli tak zwanych Saamów leśnego pogranicza. Świat jego doświadczeń, symboli i tradycji jest zakotwiczony w kulturze zależnej w dużym stopniu od rolnictwa. Tym samym nie do końca wpisuje się w esencjalistyczną wizję kultury saamskiej jako kultury hodowców reniferów.

Márkosámit są społecznościami, które ewoluowały po części z grup saamskich pasterzy z obszarów Jukkasjärvi (Północna Szwecja). W XVII i XVIII wieku z powodu coraz trudniejszego dostępu do pastwisk, a także epidemii, które trzebiły stada, niektóre tamtejsze wspólnoty zarzucały hodowlę reniferów i związany z nią półnomadyczny styl życia. Saamowie z okolic Jukkasjärvi osiedlali się w pobliżu norweskich wybrzeży w okręgach Nordland i Troms, między Ballangen na południu a Malangen na północy, gdzie znajdowały się ich letnie pastwiska. Swoje sadyby zakładali powyżej istniejących tam wcześniej norweskich gospodarstw oraz osad Saamów morskich. Márkosámit osiedlali się na łąkach pokrywających niższe partie górskich zboczy, na terenach niezagospodarowanych, graniczących z obszarami leśnymi (norw. mark). Do początku lat 20. XIX wieku trwał okres przejściowy w osiedlaniu się przybyszów z okolic Jukkasjärvi w norweskim pasie nadbrzeżnym, charakteryzujący się powstawaniem tymczasowych miejsc pobytu, opuszczanych przez mieszkańców i ich stada po wykorzystaniu zasobów danego terenu. Dopiero w latach 20. XIX wieku przyszło na świat pierwsze pokolenie márkosámit, które zmieniło definitywnie tryb życia, zakładając stałe sadyby. Badania pokazują ponadto, że społeczności Saamów leśnego pogranicza współtworzyli również Saamowie morscy zamieszkujący wybrzeża w dystryktach Nordland i Troms w pobliżu sadyb norweskich ${ }^{8}$. Powstała w ten sposób kultura rolnicza, dla której uzupełniających zasobów dostarczały pobliskie morze, a także lasy i wody lądowe9.

W Notáhtat márkosámi čoahkážis (Notatki z samego serca ziem Saamów leśnego pogranicza $)^{10}$ Skåden $\mathrm{z}$ dużą dozą dobrodusznej autoironii ukazuje specyficzną mentalność swoich ziomków:

\footnotetext{
${ }^{8}$ Przybysze z Jukkasjärvi i ich potomkowie opisywani są przez Vorrena i Mankera jako outsiderzy, których piętno obcości narażało na większą dyskryminację wśród nie-Saamów, niż to było udziałem przedstawicieli innych saamskich społeczności (Vorren i Manker 1980: 157).

9 Na temat kultury márkosámit zob. m.in. St.meld. (2007-2008); NOU (2007: 14); Andersen (2005); Vorren i Manker (1980).

${ }^{10}$ Notáhtat márkosámi čoahkážis (Notatki z samego serca ziem Saamów leśnego pogranicza) stanowiły część instalacji Kløkt/Indigenuity (Roztropność, 2012), projektu, w którym oprócz
} 


\section{Notatka 6}

Po przodkach odziedziczyło się dumę z niekupowania, z wykonywania samemu tego, co potrzeba, z tego, co już się ma. Nazywamy to zrobieniem własnego patentu.

\section{Notatka 7}

Każdy samochód ma potencjalną wartość. Niejeden taki dawca organów może kiedyś stać się pełnowartościowym produktem. Karoseryjne narządy zalegają na łące wokół domu. Po co wyrzucać, mówi, tak pięknie błyszczą w słońcu (Skåden 2017: 20).

Owe życiowe credo, przymus tworzenia nowych wartości z elementów pozornie do siebie nieprzystających, który poeta zauważa u swoich pobratymców, łączy się u niego ze swoistą estetyką kombinatoryczną. Zakłada ona między innymi wiązanie biograficznej specyfiki z innymi systemami znaczeń, czego od współczesnej sztuki oczekuje Bourriaud; zakłada łączenie odrzuconych lub zbędnych elementów w nową, niezbędną całość.

\section{Nomadyzm, czyli trop Wiecznego Tułacza}

Skåden zadebiutował poematem Skuovvadeddjid gonagas (Król szewców, 2004), który trzy lata później ukazał się w autorskim tłumaczeniu pod norweskim tytułem Skomakernes konge. Tego samego roku Skuovvadeddjid gonagas jako książka reprezentująca Sápmi uzyskał nominację do Literackiej Nagrody Rady Nordyckiej. Skuovvadeddjid gonagas jest osadzoną w latach międzywojennych i ukazaną we fragmentarycznych, poetyckich obrazach opowieścią o dwudziestotrzyletnim Jusupie (saamski wariant imienia Józef). Chłopak po dłuższej wędrówce powraca na Północ, do rodzinnych stron nad fiordem Ofot, jednak powrót do domu jawi się jako powrót do obcości:

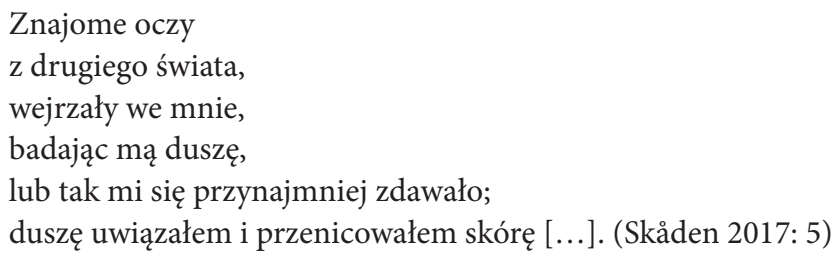

Poemat składa się z czternastu części, a warstwę słowną uzupełnia trzynaście fotografii - przeważnie przedstawiających ludzkie postacie, zarówno zastygłe

Sigbjørna Skådena wzięli udział architekt Joar Nango oraz plastyczka Silje Figenschou Thoresen. Kløkt nie jest jedynym interdyscyplinarnym projektem, w którym poezja Skådena wybrzmiewa w przestrzeni zaaranżowanej przez Nango. Przykładem jest instalacja Europe Everything 2017 na prestiżowej wystawie Dokumenta 14, organizowanej w 2017 roku w Atenach i Kassel. 
w atelier z początków XX wieku, jak i uchwycone w codziennych sytuacjach. Na czterech zdjęciach widać też istotne elementy krajobrazu - z charakterystycznym profilem wiejskiego kościółka, kołyszącym się na falach kutrem rybackim, zaoranym polem, którego krańce dotykają pokrytych lasem zboczy gór. Fotografie znacznie ułatwiają usytuowanie Skuovvadeddjid gonagas w czasie i przestrzeni.

Historia Jusupa rozgrywa się w kilku płaszczyznach czasowych. Opowieść ramowa rozciąga się między dotarciem Jusupa na rodzinny brzeg po kilkuletniej wędrówce po odległych krainach a jego samotną ucieczką z mentalnej ciasnoty rodzinnej społeczności:

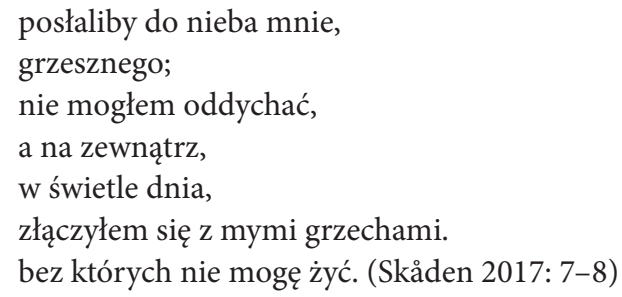

Natomiast fragmenty retrospektywne dotyczą zarówno wspomnień z dzieciństwa, jak i późniejszych lat spędzonych na obczyźnie, wypełnionych między innymi miłością do pięknej Thei.

Jusup widzi siebie jako spadkobiercę Wiecznego Tułacza, a jego doświadczenia stanowią swoistą paralelę losów jerozolimskiego szewca o imieniu Józef, którego w świetle jednego $\mathrm{z}$ wariantów legendy o Żydzie Wiecznym Tułaczu spotyka kara za znieważenie Chrystusa podążającego ku Golgocie.

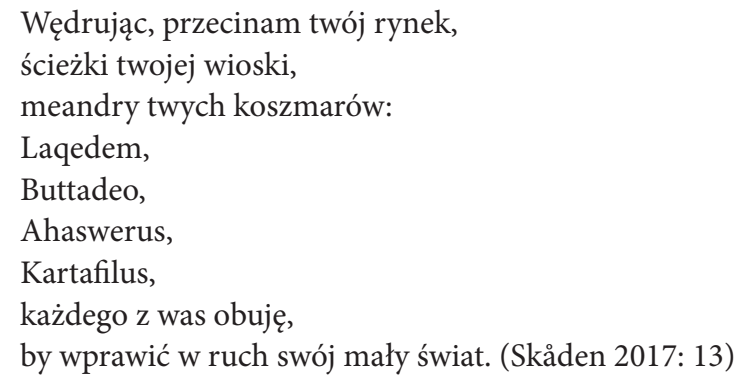

Podczas gdy tułaczka w przypadku biblijnego pierwowzoru była karą i przekleństwem, u Jusupa zdaje się jedynym wyjściem z sytuacji. Jest czynnikiem konstytuującym „wędrujące ja” - Jusup nie istnieje bez wiecznej tułaczki. Zmienność, ruch, wielość impulsów są częścią jego tożsamości. Saamski tułacz ucieleśnia cechy człowieka współczesnego - wyobcowanego, niezaznającego spokoju nawet po powrocie $\mathrm{w}$ rodzinne strony, rozdartego między tęsknotą za przekraczaniem ko- 
lejnych granic a potrzebą odczuwania wspólnotowości i przynależności do miejsca i ludzi.

Rzeczownikiem określającym Jusupa, główną postać, a zarazem lirycznego narratora w Skuovvadeddjid gonagas, jest báhtareaddji, co w języku północnosaamskim może oznaczać zarówno kogoś wyjętego spod prawa, wygnańca, banitę, jak i uciekiniera lub zbiega. Semantyczne pole báhtareaddji zaciera zatem granice między przymusem a wyborem.

Nowoczesność wędrująca niczym korzeń wypuszczany przez roślinę w zależności od jej potrzeb „penetruje jednocześnie przestrzeń geograficzną, przebieg historii i znaki kulturowe”, pisze Bourriaud (2012: 31), postrzegając włóczęgę jako najbardziej spójną postawę artystyczną. Przestrzeń, którą przemierza młody Saam w poemacie Skådena, ma nie tylko wymiar geograficzny, ale przede wszystkim mentalny i kulturowy, a także językowy: doświadczenie „południowych krain” wiąże się również z doświadczeniem językowej polifonii świata przemierzanego przez „wędrujące ja”. Owa poliglotyczność, swoiste przenikanie kultur i języków, zostaje oddane za pomocą obcojęzycznych inkrustacji, które pojawiają się w tekście stopniowo, wraz z rozwojem opowieści. Są wariacjami na temat wędrówki, najczęściej wprost przywołują warianty opowieści o Żydzie Wiecznym Tułaczu. Inkrustacje rozszczepiają poszczególne fragmenty saamskiego tekstu:

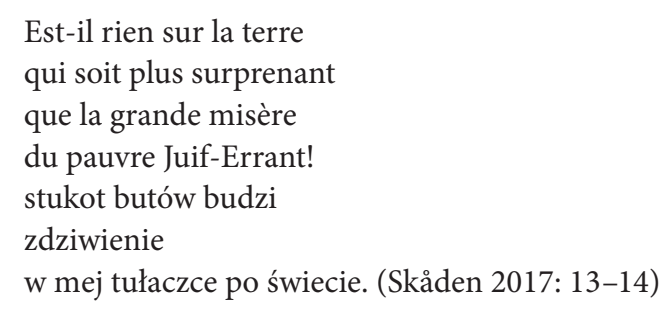

Patrząc na biografię autora Skuovvadeddjid gonagas i jego związki z kulturą márkosámit, trudno oprzeć się wrażeniu, że język tamtejszych społeczności kryje w sobie opowieść o płynności granic. Márkosámit z Troms oraz z Nordland posługują się jednym z dialektów języka północnosaamskiego, tak zwanym torne, którego źródłem były saamskie społeczności okolic szwedzkiego Jukkasjärvi (Dankertsen 2014: 9). To właśnie w takim wariancie języka północnosaamskiego, w lokalnej odmianie torne, Sigbjørn Skåden napisał swego debiutanckiego Skuovvadeddjid gonagas. Wielogłosowość poematu można zatem odczytywać jako metaforę poliglotycznej, a tym samym niejednoznacznej i pozbawionej jednego zdecydowanego centrum rzeczywistości zarówno wędrującego po świecie Jusupa, przemierzających Półwysep Skandynawski saamskich społeczności, jak i współczesnego człowieka w ogóle. Poliglotyzm jest bowiem zdaniem autorki Podmiotów nomadycznych jedną z nomadycznych cech współczesności, 
poligonem przygotowującym człowieka do krytycznego przyjrzenia się temu, co konstytuuje jego „ja”:

Osoba, która jest pomiędzy językami, ani tu, ani tam, jest zdolna do odrobiny zdrowego sceptycyzmu w kwestii gotowych tożsamości i języków ojczystych. Pod tym względem mówienie o poliglocie jest wariacją na temat krytycznej nomadycznej świadomości; znajdowanie się pomiędzy językami konstytuuje punkt obserwacyjny, z którego dekonstruuje się tożsamość (Braidotti 2009: 37).

W innym miejscu Podmiotów nomadycznych czytamy: „Słowa mają swoje sposoby, bu nie pozostawać w miejscu, by kroczyć swymi własnymi ścieżkami. Przychodzą i odchodzą, przemierzają obecne ścieżki semantyczne, pozostawiając za sobą akustyczne, graficzne czy nieuświadomione ślady" (Ibid.: 32-33). Lub jak to zostaje sformułowane w Skuovvadeddjid gonagas:

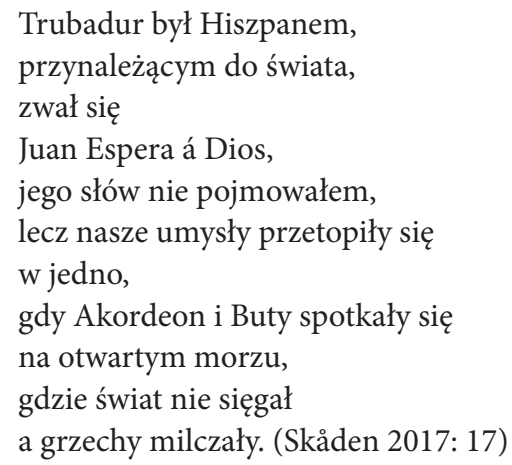

Oznacza to, że poliglotyzmu nie należy pojmować tylko i wyłącznie w kategorii posługiwania się wieloma językami narodowymi. Na przykład proces pisania, tworzenia w języku jest dla Braidotti z natury rzeczy poliglotyczny. Pisarstwo bowiem „odwraca iluzoryczną statyczność ustalonych już tożsamości”, „polega na poruszaniu osiadłej natury słów, destabilizowaniu przyjętych zdroworozsądkowych znaczeń" (Braidotti 2009: 41).

\section{Nomadyzm, czyli płynność granic etycznych}

Skåden nie stroni od artystycznych prowokacji. Jedną z nich było anonimowe wydanie blogerskiej powieści Láhppon mánáid bestejeaddji (Zbawiciel zagubionych dzieci, 2009), która rok później ukazała się w przekładzie norweskim (De fortapte barns frelser). Wydanie książki poprzedził konceptualny eksperyment autora: przez kilka miesięcy prowadził on blog, na którym przywdziewał maskę 
dziewiętnastoletniej saamskiej dziewczyny, Ihpil (Widmo). Ihpil, przeprowadziwszy się z małej miejscowości do uniwersyteckiego Tromsø, zaczyna studiować, nawiązywać znajomości, eksplorować swoją homoseksualność. Stopniowo przełamuje poczucie wyobcowania, którego źródłem jest zarówno jej saamskie pochodzenie, jak i seksualność nieprzystająca do tradycyjnej obyczajowości rodzinnej miejscowości. Przede wszystkim jednak poszukuje akceptacji i miłości ${ }^{11}$. Blog zaczynał się wpisem z 14 sierpnia 2007 roku, pierwszego dnia studenckiego życia Ihpil, a kończył 17 grudnia. Ostatnie zapiski powstały tuż przed wyjazdem blogerki do domu na ferie świąteczne: odprowadziwszy swą dziewczynę na samolot, Ihpil - po raz pierwszy z wzajemnością zakochana, wręcz upojona szczęściem, wyrażająca przekonanie, że w końcu „świat stał się miejscem, w którym można żyć" (Ihpil [Skåden] 2010: 84) - spieszy się na prom. Obiecuje kontynuować opowieść po przyjeździe do domu, jednak już nigdy więcej nie zabiera głosu.

Wydana w 2008 roku powieść stanowiła przedruk owego bloga, który nieoczekiwanie kończył się przedświątecznym wpisem. „Tekst odredakcyjny” połączył fakt zamilknięcia blogerki z odnalezieniem w portowym basenie w Troms $\varnothing$ w grudniu 2007 roku ciała saamskiej studentki. Otwarte zakończenie tekstu nie daje czytelnikowi klarownej podpowiedzi co do przyczyn śmierć Ihpil - czy nastąpiła ona na skutek nieszczęśliwego wypadku, czy też była aktem samobójczym, sposobem na uchronienie oszałamiającego uczucia miłości i wolności przed zderzeniem z realnością.

Dwa lata później mistyfikację odkryto: okazało się, że w grudniu 2007 roku nie znaleziono w Tromsø żadnego topielca, a tropy poprowadziły do Skådena, czyli „redaktora”. Sam autor, którego demaskacja była planowaną częścią projektu (choć dokonała się wcześniej, niż przewidywał pisarz), twierdził wówczas, że stworzenie bloga miało rzucić światło na naszą potrzebę żerowania na intymności drugiego człowieka, co odciska piętno zarówno na życiu społecznym, jak i kulturze popularnej. Ponadto podejmując temat homoseksualności, dotknął obszarów tabu w saamskich społecznościach, często obyczajowo konserwatywnych, pozostających pod wpływem laestadianizmu (Enge 2011; Arvola 2011) ${ }^{12}$.

Ostatnia jak dotąd powieść Skådena, Våke over dem som sover (2014), zarazem tematyzuje artystyczną prowokację, jak i stawia pytania o granice takiego działania. Våke over dem som sover wpisuje się w pozaliteracką rzeczywistość, nawiązując do skandalu obyczajowego, który wstrząsnął Kautokeino w pierwszym dziesięcioleciu

${ }^{11}$ Blog jest wciąż dostępny, a ostatnie komentarze dodano w 2014 r. (Ihpil [Skåden] 2007).

${ }_{12}$ Laestadianizm - dziewiętnastowieczny religijny nurt odrodzeniowy w kościele luterańskim, charakteryzujący się moralnym rygoryzmem oraz społecznym konserwatyzmem. Nazwa ruchu pochodzi od nazwiska pastora i botanika Larsa Læstadiusa (1800-1861), proboszcza w Karesuando w latach 1826-1849 oraz w Pajala w latach 1849-1861. 
XXI wieku: grupa mężczyzn, wśród których byli przedstawiciele lokalnych władz, została oskarżona o seksualne wykorzystywanie nieletnich dziewcząt. Niektóre z ofiar miały poniżej czternastu lat. O ile wszystkie poprzednie książki powstawały w języku północnosaamskim, o tyle Våke over dem som sover została napisana po norwesku, co stanowi próbę szybkiego i bezpośredniego dotarcia pisarza do szerszego grona odbiorców (Hoem 2014; Matland 2014). Ponadto wybór języka norweskiego jako medium odmiennie zdefiniował perspektywę narratora, ułatwiając mu zdystansowanie się do głównego bohatera i jego saamskiego otoczenia.

Akcja powieści toczy się na kilku płaszczyznach czasowych: fragmentaryczne spojrzenia na historię rodu Asmunda, głównej postaci Våke over dem som sover, sięgają kilka pokoleń wstecz, a współczesne wydarzenia związane z pobytem Asmunda w Kautokeino mają bezpośredni związek z przytaczanymi przez bohatera wspomnieniami z dzieciństwa. Książka Skådena opowiada bowiem również o wielopokoleniowym procesie wypleniania saamskiego ducha ze społeczności márkosámit: procesie, w którym poczucie wstydu z przynależności do podwójnie marginalizowanej grupy łączyło się z niechęcią wobec społeczeństwa dominującego.

Książka ma czytelne akcenty autobiograficzne - główny bohater Asmund Andersen to artysta parający się sztuką wideo, równolatek autora. Podobnie jak on pochodzi z gminy Skånland, a losy jego rodziny naznaczonej procesami norwegizacji mają niejeden punkt wspólny z życiorysami krewnych Skådena (Skåden 2011). Między innymi w Våke over dem som sover zostaje wyartykułowany motyw językowej marginalności Saamów zamieszkujących rodzinną gminę pisarza. Z sekwencji dotyczących lat szkolnych głównego bohatera dowiadujemy się, iż Asmund, który posługuje się dialektem właściwym dla márkosámit, pierwszego dnia pobytu w saamskiej szkole w Kautokeino doświadcza odtrącenia przez saamskich rówieśników: dla nich jest nie-Saamem.

Innymi słowy dla przedstawiciela márkosámit opresyjnością naznaczone były nie tylko relacje z kulturą norweską, która w sposób oczywisty definiowana była jako dominująca. Historia Asmunda pokazuje, że podobnie represyjny model cechuje relacje między saamską kulturą „wzorcową" (zakotwiczoną w tradycji hodowców reniferów, charakterystyczną m.in. dla mieszkańców Kautokeino) a społecznościami Saamów o mniej wyrazistej tożsamości etnicznej, które częściowo zasymilowały się ze społeczeństwem dominującym.

Zasadnicza część akcji toczy się współcześnie w Kautokeino. Leżąca w Finnmarku i zamieszkana w większości przez Saamów miejscowość leczy duchowe rany po niedawnym skandalu obyczajowym. Asmund, otoczony sławą bezkompromisowego i nowatorskiego artysty przygotowującego się do indywidualnej wystawy, pojawia się w Kautokeino, by poprowadzić warsztaty z gimnazjalistami. Zaufanie zdobyte dzięki autorytetowi „słynnego człowieka” oraz funkcji nauczyciela wykorzystuje w pracy nad instalacją. Artysta chce wywołać wstrząs i przerwać 
zmowę milczenia i przyzwolenia na mentalną przemoc, skutkującą odzieraniem dzieci z niewinności: przyzwolenia udzielanego również przez same ofiary w imię lokalnej solidarności „plemiennej” i patriarchalnej tradycji. Konceptualny projekt Asmunda ma w zamierzeniu przynieść katharsis społeczności Kautokeino.

Okazuje się jednak, że granica między bezkompromisowością w podążaniu za instynktem artystycznym a bezwzględnością w podążaniu za instynktem fizycznym jest w przypadku Asmunda niezwykle elastyczna. Ponadto retrospektywne sceny z dzieciństwa artysty, pokazujące między innymi brutalną, a przy okazji podstępną reakcję Asmunda na próbę odtrącenia go przez rówieśników w Kautokeino (upozorowany przez niego wypadek adwersarza podczas gry w piłkę), stawiają artystyczne wybory bohatera w dwuznacznym świetle.

Aby zrealizować swój pomysł, Asmund cynicznie uwodzi czternastoletnią Issę. Proces osaczania dziewczynki poznanej w szkole $\mathrm{w}$ trakcie prowadzenia zajęć artysta prezentuje zszokowanej publiczności w formie instalacji wideo, próbując (nie do końca skutecznie) przekonać siebie i innych, że jego działanie jest artystycznie uzasadnione, a tym samym moralnie uprawnione: „Zniszczę ich obraz siebie. Iluzję niewinności. Uniosę lustro, które pozwoli im spojrzeć w głąb siebie. A gdy się ujrzą w tym lustrze, nie pozostanie im nic innego, jak mnie znienawidzić [...], alternatywą byłoby skierowanie nienawiści ku sobie" (Skåden 2014: 118, tłum. M.S.). Powieść Skådena, podobnie jak projekt Asmunda, podstawia saamskim czytelnikom popękane lustro, a przeglądanie się w nim narusza gładką fasadę harmonijności i wspólnotowości. Działania Asmunda niczym cięcia skalpelem mają przyczynić się do uzdrowienia społeczności, która od pokoleń narażona na dyskryminację w relacjach z przedstawicielami władzy i społeczeństwa dominującego sama jest silnie zhierarchizowana i wybiera taktykę oblężonej twierdzy, przyzwalając tym samym na to, by zjawiska niszczące wspólnotę od wewnątrz pleniły się bez przeszkód.

Våke over dem som sover traktuje o władzy i jej nadużywaniu. Stawia tym samym pytanie o granice przyzwolenia na manipulowanie drugim człowiekiem, również manipulowanie drugim człowiekiem w imię nadrzędnych, ustalonych przez artystę celów. Posługując się przy tym czytelnymi odwołaniami do pozaliterackiej rzeczywistości, do łatwo identyfikowalnych środowisk, autor balansuje na granicy między krytyką artystycznej przemocy a jej praktykowaniem.

Podsumowując, można stwierdzić, że zmienna perspektywa postrzegania świata i samego siebie, jaką niesie motyw wędrówki, ale także poliglotyczny charakter literackiego universum, stawianie wyzwań granicom - w tym granicom literackiej fikcji - oraz tematyzowanie ich płynności, estetyka kombinatoryczna, polegająca na łączeniu pozornie nieprzystających elementów oraz adaptowaniu różnych 
rzeczywistości kulturowych, stanowią o nomadycznym charakterze twórczości Skådena. Jednak o nomadyczności jego pisarstwa świadczy również obecny w nich element agresji i inwazyjności grożących demontażem zastanego porządku.

\section{Bibliografia}

Andersen, T.O. (2005). Markasamiske kombinasjonsnoeringer: en undersøkelse på mikronivå 1860-1920. Praca magisterska. Tromsø: Universitetet w Tromsø, https://munin.uit.no/handle/10037/3599 (dostęp: 1.02.2017).

Arvola, Ø. (2011). Skåden var lesbisk kvinne på blogg. iTromso, http://www.itromso.no/kultur/ article427827.ece (dostęp: 20.02.2017).

Biblioteksbladet. (1922). Biblioteks-notiser. Biblioteksbladet 7: 117, http://runeberg.org/biblblad/1922/0125.html (dostęp: 20.02.2017).

Bourriaud, N. (2012). Estetyka relacyjna. Tłum. Ł. Białkowski. Kraków: MOCAK.

Braidotti, R. (2009). Podmioty nomadyczne. Ucieleśnienie i różnica seksualna w feminizmie wspótczesnym. Tłum. A. Derra. Warszawa: Wydawnictwa Akademickie i Profesjonalne.

Dankertsen, A. (2014). Samisk artikulasjon: melankoli, tap og forsoning i en (nord)norsk hverdag. Praca doktorska. Bodø: Universitetet w Nordland.

Egeland, T. (2017). Møt nestlederkandidat Sigbjørn Skåden. Den norske Forfatterforeningen, http://www.forfatterforeningen.no/artikkel/mot-nestlederkandidat-sigbjorn-skaden\#. WOdzcqKkLIU (dostęp: 1.04.2017).

Enge, M. (2011). Dagbokroman i bloggforkledning. Barnebokkrtikk, http://www.barnebokkritikk.no/modules.php?name=Reviews\&rop=showcontent\&id=828 (dostęp: 20.02.2017).

Gaski, H. (2004). Tiden er et skip som ikke kaster anker. Samiske ordtak. Karasjok: Cálliid Lágádus.

Hoem, K. (2014). Du må ikke sove. NRK, https://www.nrk.no/kultur/bok/vaker-over-den-som-sover-1.11744629 (dostęp: 22.02.2017).

Ihpil [Skåden, S.]. (2007). Láhppon mánáid bestejeaddji, http://ihpil.blogspot.no/2007/08/ (dostęp: 20.02.2017).

Ihpil [Skåden, S.]. (2008). Láhppon mánáid bestejeaddji. Evenskjer: Skániid girjie.

Ihpil [Skåden, S.]. (2010). De fortapte barns frelser. Evenskjer: Skániid girjie.

Jalvi, P. (1915). Muottačalmit. Jyväskylä: Gummerus.

Jonsson, E. (2017). Sigbjørn Skåden. Versepolis, http://www.versopolis.com/poet/67/sigbjrnskden (dostęp: 20.02.2017).

Kendzior, N. (2001). Med lavvu i transit. Krit.sirkelen 20: 43-44.

Larsen, A. (1912). Bæivve-Alggo. Kristiania: Grøndahl.

Lukkarari, R.M. (1986). Losses beaivegirji. Kautokeino: DAT.

Lundmark, B. (2016). Samepoeten Pedar Jalvis dikter berör fortfarande. LT, http://www.ltz.se/ kultur/bocker/samepoeten-pedar-jalvis-dikter-beror-fortfarande (dostęp: 3.08.2017).

Matland, M. (2014). Dette har gitt han større lesekrets. iTromso, http://www.itromso.no/kultur/ article10039181.ece (dostęp: 22.02.2017).

NOU 2007: 14. Samisk naturbruk og retts-situasjon fra Hedmark til Troms - Bakgrunnsmateriale for Samerettsutvalget. Oslo: Avgitt til Justis- og politidepartementet, https://www.regjeringen.no/no/dokumenter/stmeld-nr-28-2007-2008-/id512814/sec3 (dostęp: 22.03.2017).

Sibińska, M. (2015). Krajobraz nomadyczny w Muittalus samid birra (1910) Johana Turiego. Prace Etnograficzne 43 (2): 141-154. 
Sibińska, M. (2016). Saamskie teatry. Między lokalnością a obcością? Folia Scandinavica Posnaniensia 19 (1): 233-250.

Skåden, S. (2004). Skuovvadeddjiid gonagas. Evenskjer: Skániid girjie.

Skåden, S. (2007). Skomakernes konge. Evenskjer: Skániid girjie.

Skåden, S. (2009). Prekariáhta lávlla. Evenskjer: Skániid girjie.

Skåden, A. (2011). Beaivvážá mánák! Samiskopploringa i Skånland fra 1987-1995, http://skuvla.info/skolehist/beaivvaza-tn.htm (dostęp: 1.02.2017).

Skåden, S. (2012). Samer. Oslo: Cappelen Damm.

Skåden, S. (2014). Våke over dem som sover. Oslo: Cappelen.

Skåden, S. (2017). Robienie własnego patentu = Making one’s own patent = Å lage en egen patent = Reidet iežas patentta. Tłum. pol. M. Sibińska i S. Lund; tłum. ang. i norw. S. Skåden. Gdańsk: Instytut Kultury Miejskiej.

St.meld. nr 28 (2007-2008). Arbeids- og sosialdepartementet, https://www.regjeringen.no/no/ dokumenter/stmeld-nr-28-2007-2008-/id512814/sec3 (dostęp: 20.02.2017).

Turi, J. (1910). Muittalus samid birra = En bog om lappernes liv. Stockholm: I distribution Nordiska bokhandeln.

Utsi, P. (1974). Giela giela. Uppsala: Almqvist \& Wiksell.

Utsi, P. (1980). Giela gielain. Porjus: nakładem autora.

Utsi, P. (1992). Don čanat mu alccesat. Guovdageaidnu: DAT.

Uvaag, P. (2015). Samisk multikunstner. Morgenbladet, 31 lipca 2015, https://morgenbladet. no/2015/07/samisk-multikunstner (dostęp: 20.02.2017).

Valkeapää, N.-A. (1988). Beaivi, áhčážan. Guovdageaidnu: DAT.

Valkeapää, N.-A. (2001). Eanni, eannázan. Guovdageaidnu: DAT.

Vorren, Ø. i E. Manker. (1980). Lapończycy. Zarys historii kultury. Tłum. T.A. Malanowski. Warszawa: PIW. 